\title{
Functional Antagonism Between Vorinostat and Temozolomide when Combined with Ionizing Radiation (IR) in Glioblastoma
}

\author{
Y. R. Lawrence \\ Thomas Jefferson University \\ Y. Liu \\ Thomas Jefferson University \\ B. Andersen \\ Thomas Jefferson University \\ X. Xia \\ Merck Research Laboratories
}

\begin{abstract}
A. P. Dicker
Thomas Jefferson University Follow this and additional works at: https://jdc.jefferson.edu/bodinejournal

Part of the Oncology Commons

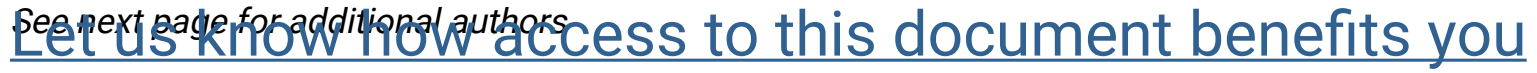

\author{
Recommended Citation \\ Lawrence, Y. R.; Liu, Y.; Andersen, B.; Xia, X.; Dicker, A. P.; and Wachsberger, P. (2010) "Functional \\ Antagonism Between Vorinostat and Temozolomide when Combined with lonizing Radiation (IR) in \\ Glioblastoma," Bodine Journal: Vol. 3 : Iss. 1 , Article 2. \\ DOI: https://doi.org/10.29046/TBJ.003.1.001 \\ Available at: https://jdc.jefferson.edu/bodinejournal/vol3/iss1/2
}

This Article is brought to you for free and open access by the Jefferson Digital Commons. The Jefferson Digital Commons is a service of Thomas Jefferson University's Center for Teaching and Learning (CTL). The Commons is a showcase for Jefferson books and journals, peer-reviewed scholarly publications, unique historical collections from the University archives, and teaching tools. The Jefferson Digital Commons allows researchers and interested readers anywhere in the world to learn about and keep up to date with Jefferson scholarship. This article has been accepted for inclusion in Bodine Journal by an authorized administrator of the Jefferson Digital Commons. For more information, please contact: JeffersonDigitalCommons@jefferson.edu. 
Functional Antagonism Between Vorinostat and Temozolomide when Combined with lonizing Radiation (IR) in Glioblastoma

\section{Authors}

Y. R. Lawrence, Y. Liu, B. Andersen, X. Xia, A. P. Dicker, and P. Wachsberger 


\title{
Functional Antagonism Between Vorinostat and Temozolomide when Combined with Ionizing Radiation (IR) in Glioblastoma
}

\author{
Lawrence, Y.R., ${ }^{1}$ Liu, Y., ${ }^{1}$ Andersen, B. ${ }^{1}$ Xia, X., ${ }^{2}$ Dicker, A.P., ${ }^{1}$ Wachsberger, P. ${ }^{1}$ \\ ${ }^{1}$ Department of Radiation Oncology, Thomas Jefferson University and Hospitals, Philadelphia, PA \\ ${ }^{2}$ Merck Research Laboratories, North Wales, PA
}

\section{Background}

Glioblastoma is the most common primary adult brain tumor. Surgery followed by radiation therapy in combination with temozolomide (Tmz) produces a median survival of 14.6 months. Tmz is a DNA akylating agent that leads to the mispairing of guanine residues with thymine. An intact mismatch-repair mechanism (MMR) converts the mispaired thymine into a lethal double-strand DNA break. Vorinostat (SAHA), an HDAC inhibitor, has been shown to act as a radiosensitizer, possibly through inhibition of DNA repair. SAHA has successfully been combined with a number of cytotoxic agents. We hypothesized that SAHA would further potentiate the radiosensitizing properties of $\mathrm{Tmz}$ in glioblastoma.

\section{Materials/Methods}

Experiments were performed with 2 glioblastoma cell lines (U87, LN18). DNA double strand breaks were quantified by both neutral comet assay and gamma-H2AX immunohistochemistry. Assays were performed immediately, and 24 hours after IR to assess DNA damage and repair respectively. For the neutral comet assay the dose of radiation was $30 \mathrm{~Gy}$ and the 'olive moment' was scored. The magnitude of the olive moment correlates with increasing DNA damage. For gamma-H2AX assay, the dose of radiation was 2 Gy and the percentage of cells with more than 3 foci was scored. Quantitative PCR and clonogenic cell survival were performed using standard techniques.

\section{Results}

In the absence of drug, radiation induced DNA-double strand breaks were almost completely repaired within 24-hours. In U87 both Tmz + IR, and SAHA + IR increased the olive moment compared to IR alone (24 hour post IR time-point). When Tmz and SAHA were combined together with IR, the olive moment decreased to 6.5 as compared to $\mathrm{Tmz}+$ IR alone $8.7(\mathrm{p}<0.05)$. Similarly, in the absence of IR, SAHA was found to decrease Tmz induced DNA damage. Comparable results were obtained with gamma- $\mathrm{H} 2 \mathrm{AX}$ assay and with the LN18 cell line. Clonogenic radiation survival assay demonstrated $\operatorname{Tmz}+$ SAHA to be no more effective than Tmz alone in potentiating the cytotoxic effect of IR. On qPCR, SAHA was found to down-regulate MLH1, MLH3, MSH2 and MSH 3, key genes involved in MMR.

\section{Conclusion}

Both Tmz and SAHA individually potentiated the effect of IR, inhibiting the repair of DNA double strand breaks. However, when cells were exposed to both drugs together less DNA damage was seen than with Tmz alone. Based upon qPCR data we hypothesize that SAHA down regulates the MMR pathway. Our work demonstrates that the addition of an HDAC inhibitor to cytotoxic agents may produce unexpected antagonism.

Research sponsored by Merck. 